\title{
A Braille Press Project: Improving the Literacy of the World's Visually Impaired
}

\author{
Daniel Blood \\ Senior, Department of Mechanical Engineering \\ Valparaiso University \\ Valparaiso, IN 46383 \\ Daniel.Blood@valpo.edu \\ Brian Koch \\ Junior, Department of Mechanical Engineering \\ Valparaiso University \\ Valparaiso, IN 46383 \\ Brian.Koch@valpo.edu \\ Marjorie Ballun \\ Junior, Department of Mechanical Engineering \\ Valparaiso University \\ Valparaiso, IN 46383 \\ Jorie.Ballun@valpo.edu \\ Mark M. Budnik \\ Assistant Professor, Department of Electrical and Computer Engineering \\ Valparaiso University \\ Valparaiso, IN 46383 \\ Mark.Budnik@valpo.edu \\ G. Scott Duncan \\ Assistant Professor, Department of Mechanical Engineering \\ Valparaiso University \\ Valparaiso, IN 46383 \\ Scott.Duncan@valpo.edu
}

\begin{abstract}
Valparaiso University engineering students have completed a service learning project to design and manufacture an upgraded braille printing press for Lutheran Braille Workers, Inc., a charitable organization that provides free-of-charge, Christian print material to visually impaired individuals around the world. There are approximately 314 million blind and visually impaired individuals around the world and the need for braille print material is significant. Braille presses are used by Lutheran Braille Workers, Inc., volunteers at work centers where the braille print material is produced. Moreover, the braille press is a critical component of the production process. The project provided multiple engineering students the opportunity to design, manufacture, and implement an actual product that will benefit visually impaired individuals around the world.
\end{abstract}


Index Terms - Braille, design and manufacture for service, print press, visual impairment.

\section{Introduction}

During the spring of 2008, Valparaiso University engineering students began a service learning project in collaboration with Lutheran Braille Workers, Inc. (LBW), ${ }^{\mathrm{i}}$ with the goal of designing and manufacturing a new generation of braille presses to replace a 60 year old design. Although the existing presses were functioning adequately, many opportunities existed to improve the safety, ergonomics, cost effectiveness, and ease of manufacture of the press. In addition to providing LBW with an upgraded braille press, this service learning opportunity allowed the students to participate in an actual product development project. The upgraded braille press is currently in operation at the Prince of Peace Lutheran Church in Valparaiso, Indiana. Although the upgraded braille press was produced for LBW, the press can be used to produce braille print material for any organization and the complete print package of the design is available. It should also be noted that the students that worked on the project did not participate in the production or distribution of any print material for LBW.

This paper describes the development and implementation of a new generation of a braille printing press and the service learning experience of seven Valparaiso University College of Engineering (VUCOE) students. First, background information is provided on the need for braille print material, LBW, the VUCOE, the braille production process, and the original braille printing press. Second, the customer requirements for the new braille press are identified. Next, this upgraded braille press design is discussed along with its required manufacturing and assembly tasks. Finally, the service learning aspects of the project are discussed.

Need for Braille Print Material:

\section{Background}

Visual impairment and literacy among the visually impaired is a significant problem. Around the world, 45 million people are blind and another 269 million individuals suffer from other visual imparities. Eighty-seven percent of the blind and visually impaired population lives in developing countries. ${ }^{\text {ii }}$ In many developing countries, the prevalence of blindness in the population is 300 to 500 percent higher than in the United States or Western European countries (see Figure 1). ${ }^{\text {iii }}$ Women are particularly susceptible to visual impairment for two reasons: 1) they have a longer life expectancy and visual impairment disproportionately affects the elderly, and 2) in many developing countries they often lack access to medical services. ${ }^{\text {iv }}$ 


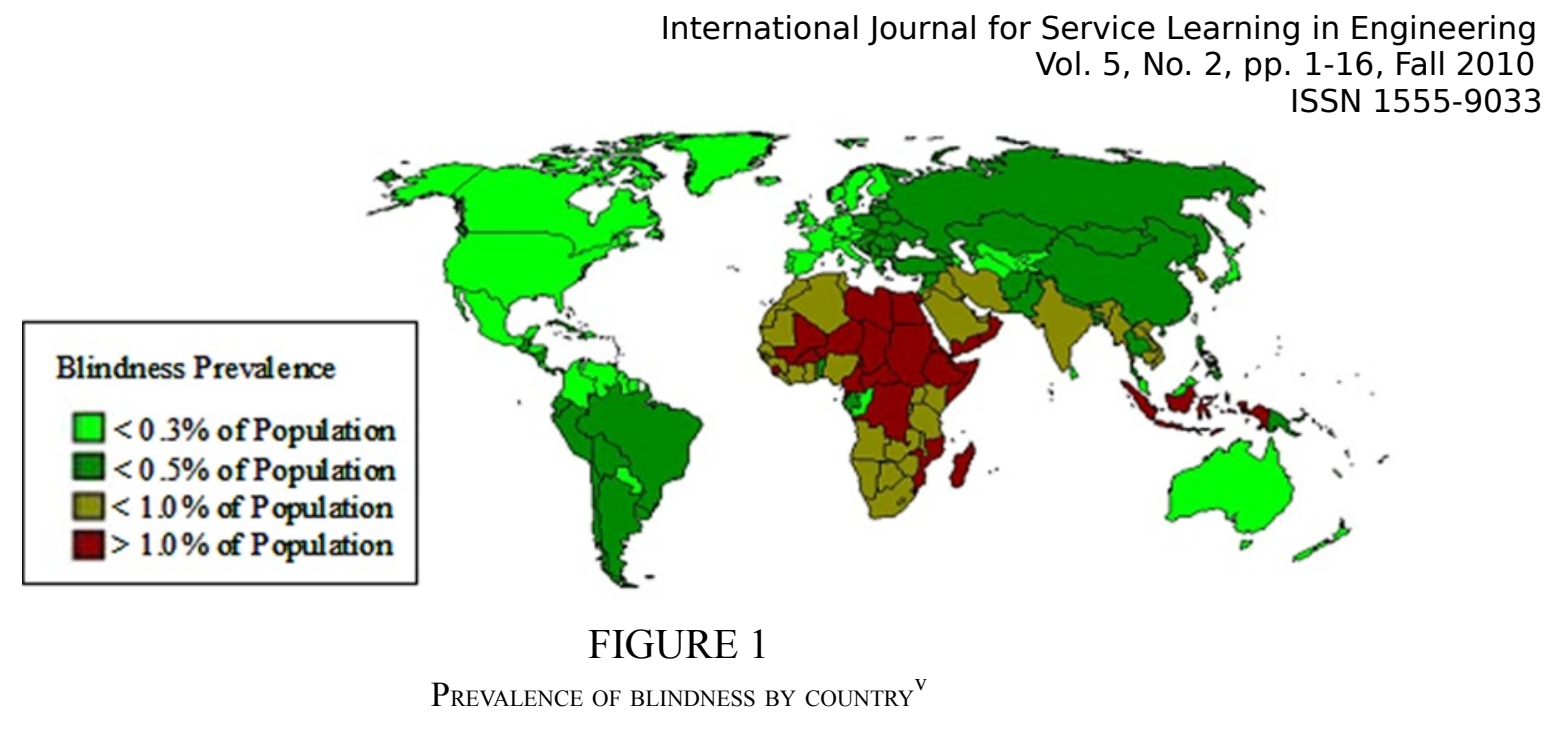

Overall statistics for the literacy rate of blind and visually impaired individuals are not widely available; however, data is available from some countries. For example, in the United States approximately 9 percent of blind students primarily use braille in their studies. ${ }^{\text {vi }}$ In Pakistan, only 14 percent of blind students are literate, and only 26 percent receive any education. ${ }^{\text {vi, viii }}$

The financial impact of blindness and vision impairment (i.e., medical care, lost wages, etc.) across the world is significant. Its annual global economic impact in 2000 was 42 billion U. S. dollars. This figure is expected to rise to 110 billion U. S. dollars in $2020{ }^{\text {ix }}$ These large numbers are due in part to the low rate of employment for the blind. A direct correlation has been shown between braille literacy and employment rate. Blind individuals that do not read braille have an unemployment rate of 77 percent as compared to blind braille literate individuals that have an unemployment rate of 44 percent. For individuals considered to be "extensive" braille readers, the unemployment rate fell to 33 percent. ${ }^{\mathrm{x}}$

Some studies have also shown that braille literacy improves communication skills. A Canadian study determined that short stories written by blind students that were braille illiterate were more poorly organized than their braille literate counterparts, "... as if all of their ideas are crammed into a container, shaken and thrown randomly onto a sheet of paper like dice onto a table." The same study determined that the stories written by braille illiterates were more likely to include non-realistic characters or story lines than their braille literate counterparts. ${ }^{\mathrm{xi}}$

One factor that contributes to braille illiteracy is the prohibitive cost of braille books throughout most of the world. For example, the American Heritage Student's Dictionary for secondary students (1,024 pages) lists for $19.95 \mathrm{U}$. S. dollars. ${ }^{\text {xii }}$ The same dictionary is available in braille in 31 volumes ( 9,180 pages) at a cost of 1,305 U. S. dollars ${ }^{\text {xiii }}$ from the world's largest nonprofit organization that creates products and services for the visually impaired. ${ }^{\text {xiv }}$ Therefore, a need exists for low cost braille books.

Lutheran Braille Workers, Inc.:

LBW is a nonprofit organization founded in 1943 that produces Christian print material in braille and large print and offers it without charge to needy individuals. The mission of LBW is: "To provide the message of salvation, through faith in Jesus Christ to individuals who are blind or visually impaired throughout the world. ${ }^{\text {xv" }}$ Approximately 200 work centers are located throughout the United States and Canada where approximately 5000 volunteers produce the Christian print material. Although commercial braille presses are available for increased production rates, LBW produces the braille print material using volunteer staffed work centers and less complicated, less expensive presses because the 
volunteers are directly involved in the production process. Therefore, more individuals participate in the charitable activity, leading to a greater sense of satisfaction. More than 250 thousand individual books of the bible (see Figure 2) are produced each year in more than 30 languages and shipped to visually impaired people in more than 120 countries around the world. In 2009, over 11 million sheets of braille material were produced by LBW. ${ }^{\mathrm{xi}}$

\section{Valparaiso University College of Engineering:}

The VUCOE ${ }^{\mathrm{xvii}}$ is an exclusively undergraduate college located in Valparaiso, Indiana. The VUCOE offers degrees in mechanical engineering, civil engineering, and electrical and computer engineering and approximately 70 students graduate each year in these three disciplines. Students are able to participate in service learning activities as a senior design project, for technical elective credit, or as a volunteer activity. The students participating in the braille press project volunteered or received technical elective credit for their contributions.

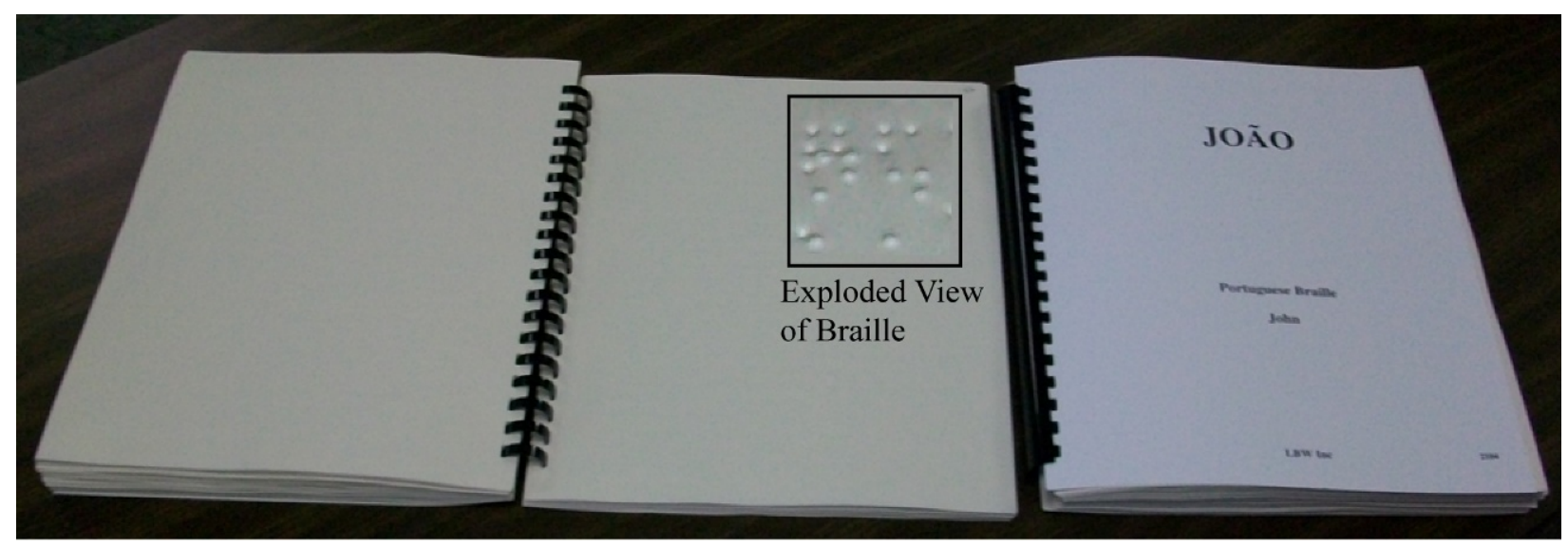

FIGURE 2

Book of John (Portuguese) in Braille

When determining which service learning opportunities to pursue, the VUCOE considers many aspects of the sponsoring charitable organization. Faculty review the organization's legitimacy, transparency, history, mission, activities, and needs. If a service learning partnership is feasible, students are presented with the organization's information and the project requirements. Irrespective of whether the students receive credit for participating in the project, student participation is completely voluntary. Moreover, students of all backgrounds are invited to participate. Overall, faculty strive to provide a variety of service learning opportunities. Previous or current opportunities include: 1) Engineers Without Borders projects, 2) wind power projects in Nicaragua, and 3) assistive technology equipment for individuals with a range of disabilities.

\section{Braille Bible Production Process:}

To produce braille print material, an LBW work center requires a braille press, embossed zinc plates, aluminum jackets, and special paper. Each sheet of the book of the Bible is represented by a pair of embossed zinc plates (see Figure 3) which contain raised dots. These raised dots correspond to the braille characters associated with that particular sheet of the book. The braille paper is placed between the two embossed zinc plates and inserted into an aluminum jacket (see Figure 3). The inside of the jacket plates are rubber coated. During production, the braille press compresses the aluminum jacket 
and embossed zinc plates. When compressed, the embossed top plate creates braille characters on one side of the paper sheet and the embossed bottom plate creates braille characters on the second side of the sheet. Therefore, both sides of the sheet are simultaneously printed and can be read by the visually impaired individual.

The current braille Bible production process is multifaceted and includes a large variety of parallel and serial tasks. The VUCOE engineering students were not asked to optimize the existing LBW production process. However, to illustrate the use of the upgraded braille press, a description of the braille Bible production process is included in the next paragraph.

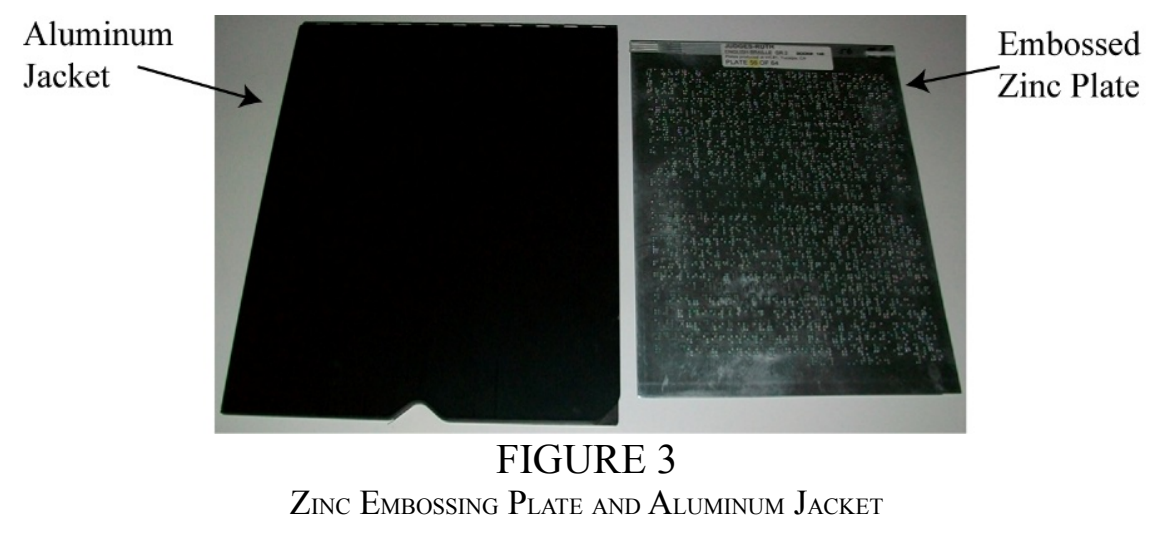

The current LBW production process is shown in Figure 4. Prior to production, the zinc plates are arranged in the sequence of the completed book and the braille press is located at the end of the sequence. Once production begins, Volunteer One places the embossed zinc plates and paper in an aluminum jacket and passes the jacket to Volunteer Two. Volunteer Two inserts the jacket into the press where two rubber rollers compress the jacket and emboss the paper with the zinc plates' patterns. Once the aluminum jacket exits the braille press, Volunteer One removes the zinc plates and embossed sheet from the jacket and passes the plates and sheet to Volunteer Three. Next, Volunteer Three gives Volunteer One the next set of zinc plates (with a blank sheet inserted between the plates). Volunteer One then places these zinc plates and paper in the aluminum jacket. Volunteer Three also removes the embossed paper, gives the embossed paper to Volunteer Six, inserts a new sheet of paper between the zinc plates, and passes the zinc plates (with the inserted paper) to Volunteer Four. Volunteer Four then places the plates from Volunteer Three at the end of the zinc plate queue. Additionally, Volunteer Four with Volunteer Five is responsible for moving the zinc plates into the correct queue positions. One additional volunteer is required. Volunteer Six receives the embossed paper from Volunteer Three, punches the binding holes in the paper, and binds the book of the Bible upon completion. The six volunteers can produce approximately 1400 sheets of braille in a day. 


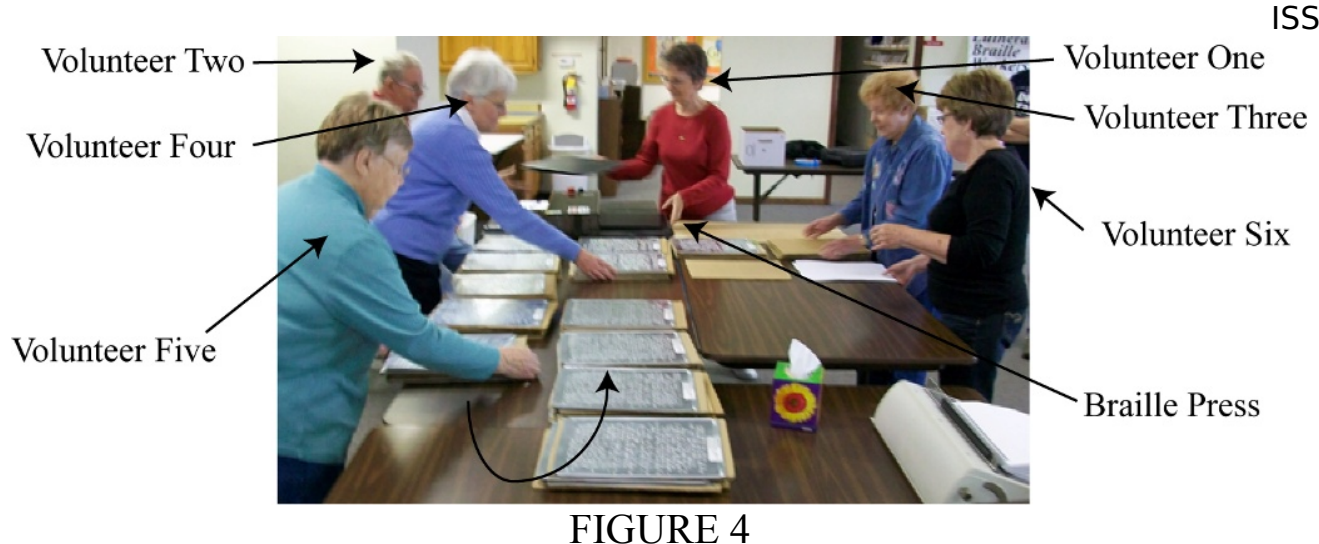

ISSN 1555-9033

Braille Bible Assembly Line at Prince of Peace Work Centre

Original Braille Press Design:

The original braille press design (see Figure 5) is approximately 60 years old and costs approximately 1,400 U. S. dollars. The frame and guards are constructed of wood and the press sits on an independent table. Underneath the roller guard, two rubber coated rollers are supported by pillow block bearings (see Figure 6) which allow the rollers to rotate with minimum friction. To produce the correct braille dot height, the amount of compression as the jacket passes between the rollers is critical; therefore, the distance between rollers is critical. This distance is set by placing shim stock of the required thickness between the pillow block bearings. The top roller turns freely and the bottom roller rotates at 42 revolutions per minute (rpm). The bottom roller is driven by a fan cooled, 120 VAC gearmotor acting through a right-angle worm gearbox and flexible coupling (see Figure 6). The right-angle worm gearbox reduces the speed from $1,800 \mathrm{rpm}$ at the motor shaft to $42 \mathrm{rpm}$ at the roller and the flexible coupling accounts for shaft misalignment between the motor shaft and roller shaft. The entire drive system is located adjacent to the roller guard and extends above the jacket entrance (see Figure 5). When a hinged plate located at the front of the press entrance is in the up position, power (provided by a standard wall outlet) is interrupted to the gearmotor. To allow for roller cleaning, the roller guard enclosure can be removed without a tool by releasing a guard latch.

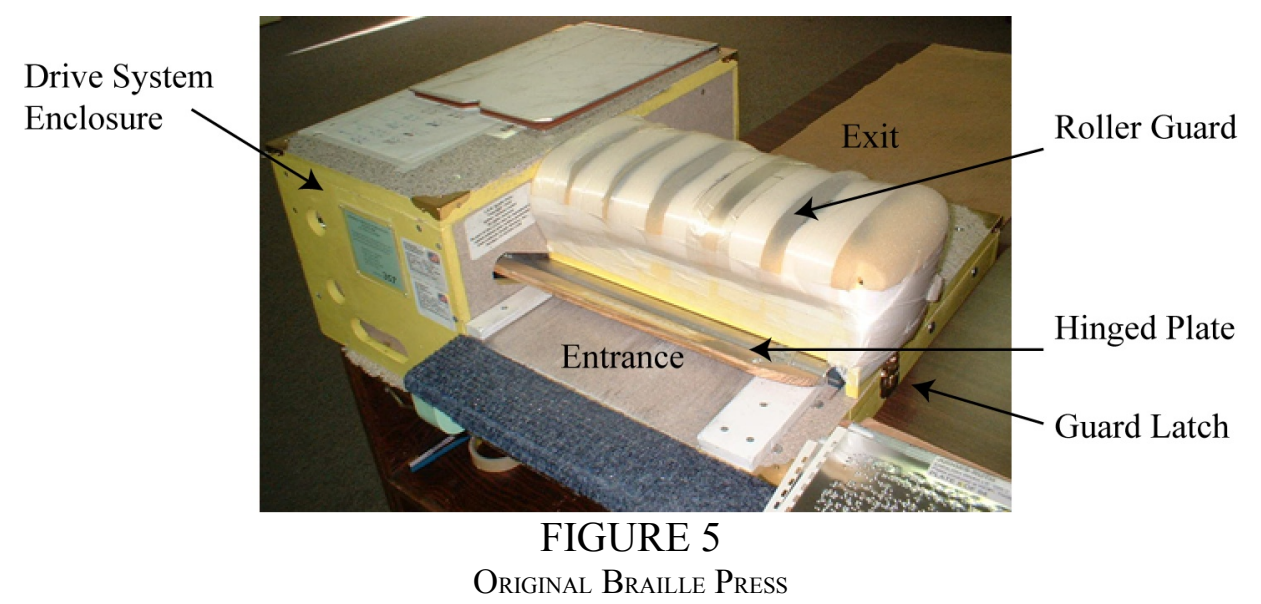




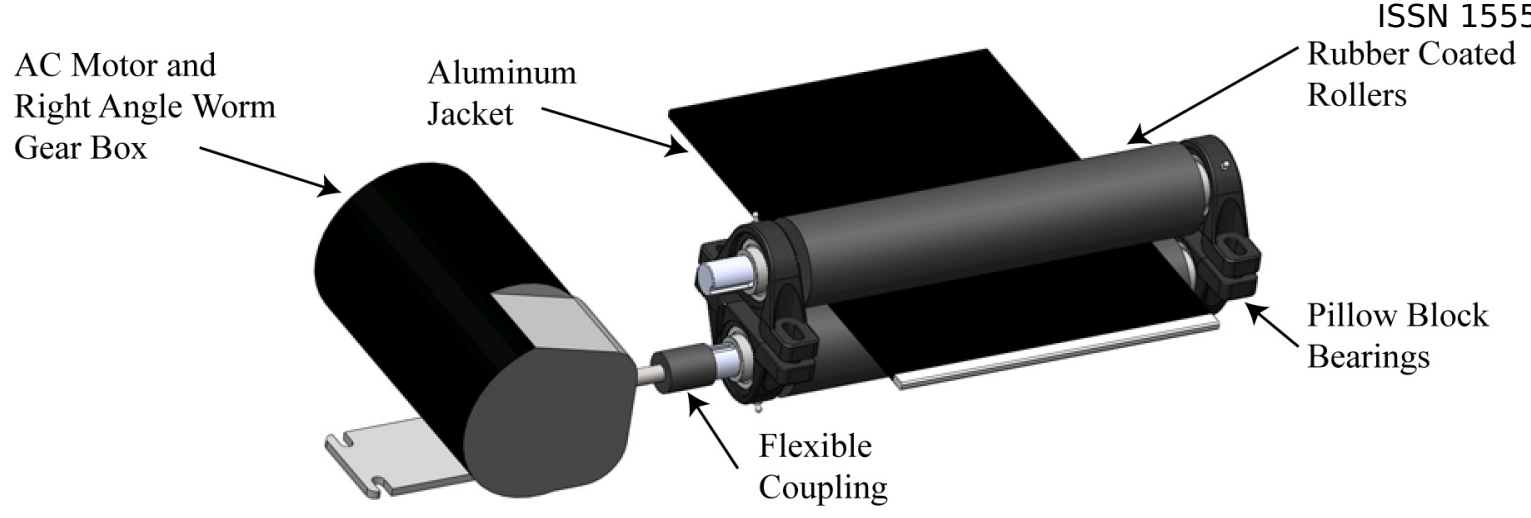

FIGURE 6

Computer Aided Design Drawing of Original Braille Press Drive System

\section{Customer Requirements}

To determine the customer requirements for an upgraded braille press, students received input from multiple individuals. These individuals included LBW representatives, volunteers at the Prince of Peace work center, maintenance personnel who service the original presses, a practicing mechanical engineer familiar with the original press, and VUCOE faculty. From this input, a desired list of improvements for a new press design was created (see Table 1).

TABLE 1

Upgraded Braille Press Requirements

\begin{tabular}{lll}
\hline Number & Upgraded Press Requirement & Justification \\
\hline 1 & $\begin{array}{l}\text { Must produce high quality braille } \\
\text { Must perform reliably }\end{array}$ & $\begin{array}{l}\text { The print material must be legible and robust } \\
\text { Only two LBW maintenance personnel are } \\
\text { available to serve 200 work centers }\end{array}$ \\
3 & $\begin{array}{l}\text { Must meet applicable Occupational } \\
\text { Meeting OSHA requirements are an obligation } \\
\text { of LBW and the VUCOE }\end{array}$ \\
4 & $\begin{array}{l}\text { Safety and Health Administration } \\
\text { requirements }\end{array}$ & $\begin{array}{l}\text { Meetiing ergonomic requirements are an } \\
\text { obligation of LBW and the VUCOE }\end{array}$ \\
5 & $\begin{array}{l}\text { Must have improved ergonomics when } \\
\text { compared to original press }\end{array}$ & $\begin{array}{l}\text { The amount of donor funds to pay for new } \\
\text { presses is limited }\end{array}$ \\
6 & $\begin{array}{l}\text { Must cost no more than original press } \\
\text { Must be as small as possible and } \\
\text { provide for jacket storage }\end{array}$ & $\begin{array}{l}\text { The work centers have limited storage available } \\
\text { Must be maintenance friendly }\end{array}$ \\
& $\begin{array}{l}\text { Only two LBW maintenance personnel are } \\
\text { available to serve 200 work centers }\end{array}$ \\
\hline
\end{tabular}

\section{Upgraded Braille Press Design}

Based on the customer requirements, a design for the upgraded braille press was developed. The upgraded press design is based upon the original press design. Therefore, the student's were not required to perform analysis on specific areas of the design such as motor sizing, the distance between rollers, roller sizing, and roller rotational speed. Rather, the students focused their efforts on improving the safety, maintenance, ergonomics, cost, ease of manufacture and assembly, and size and storage capabilities of the press. The upgraded braille press design has gone through three iterations. The final 
iteration (see Figure 7) has been in operation since April, 2010, at the Prince of Peace work center and is producing braille books of the Bible to specification.

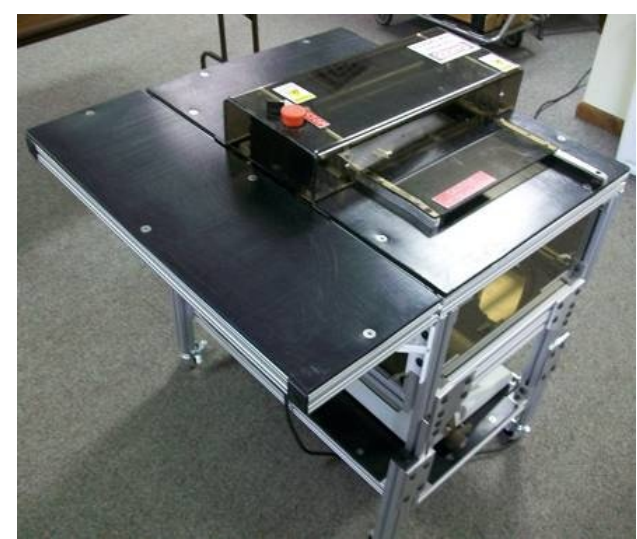

FIGURE 7

Upgraded Braille Press

\section{Overview}

The upgraded braille press design includes a new drive system and frame. The drive system is incorporated into a roller and drive subassembly (see Figure 8). This subassembly contains two rubber coated rollers that are supported by flanged bearings at each end. The bolts which attach the flanged bearings to the roller subassembly end plates are undersized in the flanged bearing clearance holes. Therefore, the flanged bearing location can be adjusted, allowing the distance between the rollers to be set to the specified dimension. As in the original press, the braille characters are embossed into the paper when the aluminum jacket, embossed zinc plates, and paper are compressed between the rollers. A 120 VAC gearmotor, located below the table, drives the bottom roller through a parallel gearbox and timing belt. The timing belt was specified so that the motor would stall before the belt failed. As in the original press design, the bottom roller rotates at $42 \mathrm{rpm}$. The roller and drive subassembly is supported by a frame constructed of aluminum extrusion (see Figure 7). Lockable casters underneath the frame assembly allow the unit to be rolled to a location and locked into place. Specific design details will be provided in the following subsections. 


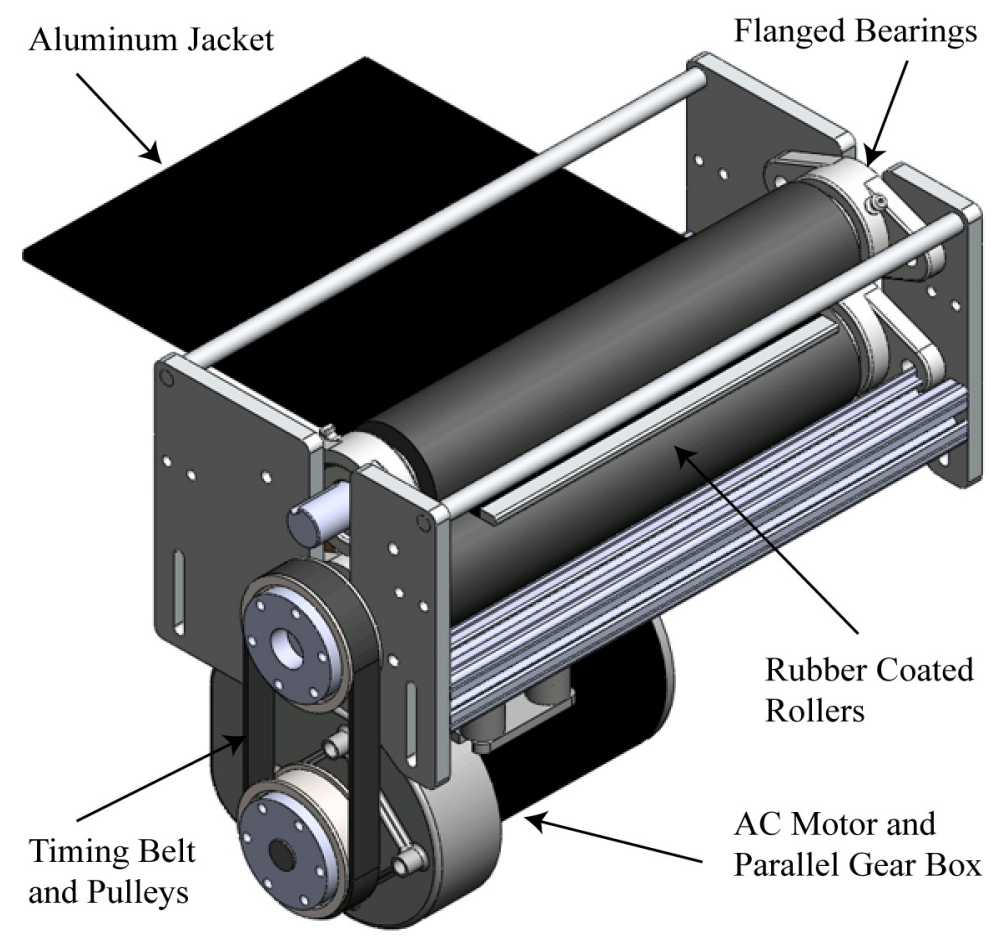

FIGURE 8

Computer Aided Design Drawing of Upgraded Braille Press Roller and Drive Subassembly

\section{Safety:}

The upgraded braille press meets all applicable Occupational and Safety Health Administration (OSHA) safety requirements. As shown in Figure 9, the press includes zero access guarding. With zero access guarding, an individual is not able to reach any machine component that can cause harm, and all pinch points have been eliminated. For example, the guarding on the inlet to the rollers is a tunnel sized so that a volunteer cannot reach the rollers with her fingers. Additionally, the upgraded braille press requires a tool to remove any guards. The upgraded braille press also includes an On/Off switch and a separate safety rated, emergency stop switch. When the emergency stop switch is pressed, all power to the press is interrupted. Finally, the upgraded braille press includes decals that warn of potential safety hazards (i.e., do not operate without guards in place, etc.).

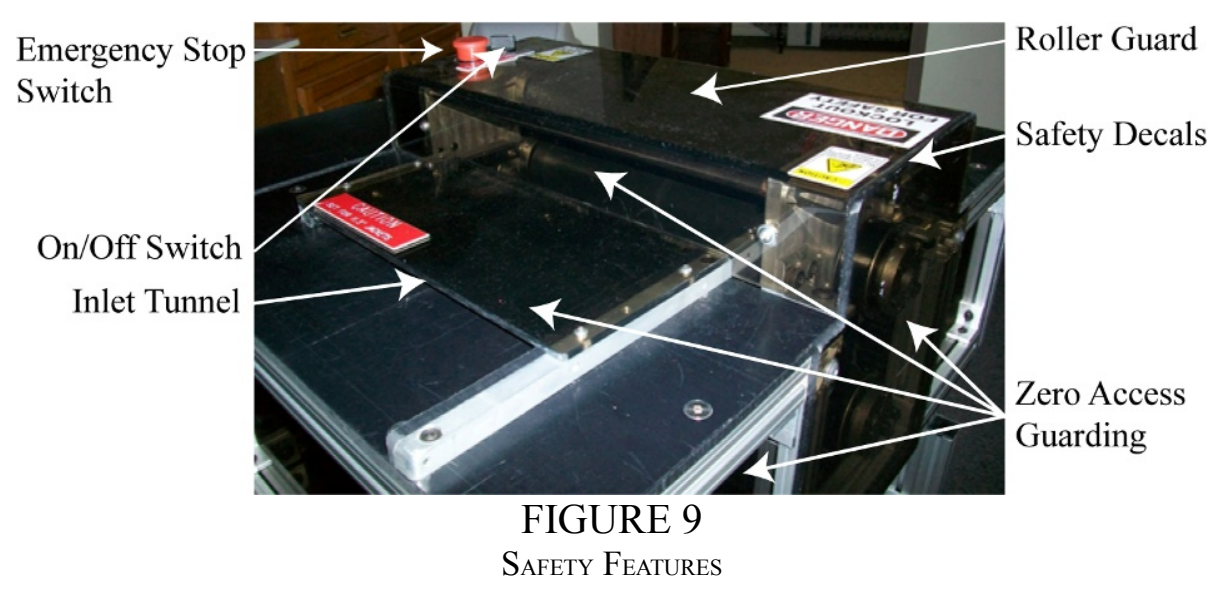




\section{Maintenance:}

The upgraded braille press incorporates two features to improve the maintenance of the unit. First, the roller and drive subassembly can be removed from the frame (see Figure 10). Because it can be removed from the frame, the subassembly can be shipped back to LBW for repairs and a replacement unit can be immediately shipped to the work center. This reduces the need for maintenance personnel to travel to the work center if any subassembly component fails. Second, the roller guard is constructed from one piece of bent plastic (see Figure 9) that can be detached by removing four bolts. With the roller guard detached, volunteers can easily perform the most frequent maintenance task, cleaning the rollers.
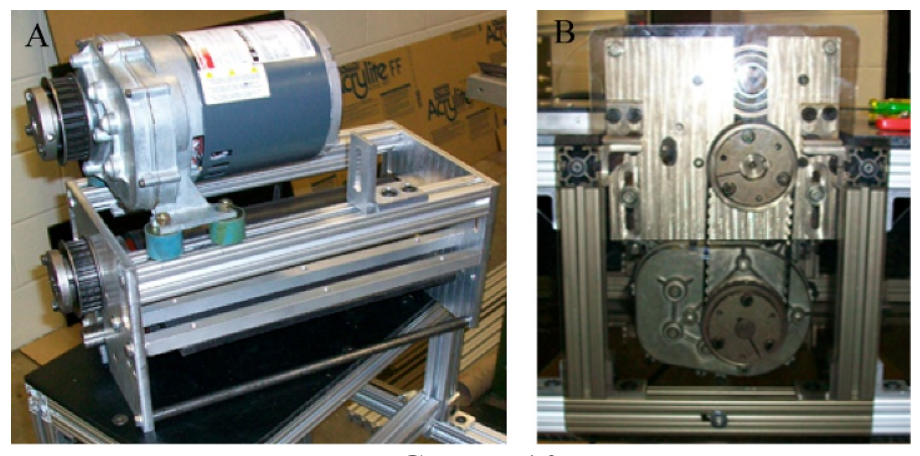

FIGURE 10

Roller and Drive Unit Subassembly: (a) outside machine, (B) in final assembly

\section{Ergonomics:}

The most important ergonomic implementation is the table top design (see Figure 7). Many of the volunteers have difficulty lifting the aluminum jackets and passing them over the top of the original press from the press exit back to Volunteer Two at the jacket inlet. This task of passing the aluminum jackets is performed once per sheet (approximately 1,400 times per day). Therefore, the customer requested a method to pass the jackets to Volunteer Two without lifting them. In the upgraded braille press, lifting the jackets is no longer required. The jackets can be returned to Volunteer Two at the press inlet by sliding them across a low friction, high density polyethylene table top. To implement this ergonomic change, the motor was moved below the rollers, requiring the bottom roller to be driven through a timing belt and pulley drive system.

Two additional ergonomic improvements were implemented in the upgraded braille press. Because work centers require presses with different table top heights, the upgraded braille press table top height is adjustable (see Figure 11). This height can be adjusted by loosening the bolts that attach the height adjustment plate to the frame and then sliding the legs to a new position. The upgraded braille press also addressed the ergonomic concerns of excessive noise and vibration levels. The original press had a wooden frame construction which absorbed much of the motor's vibration and noise. Because the upgraded braille press uses aluminum and plastic construction (materials which do not damp sound and vibration well), vibration isolators were mounted between the motor and the frame (see Figure 12). 


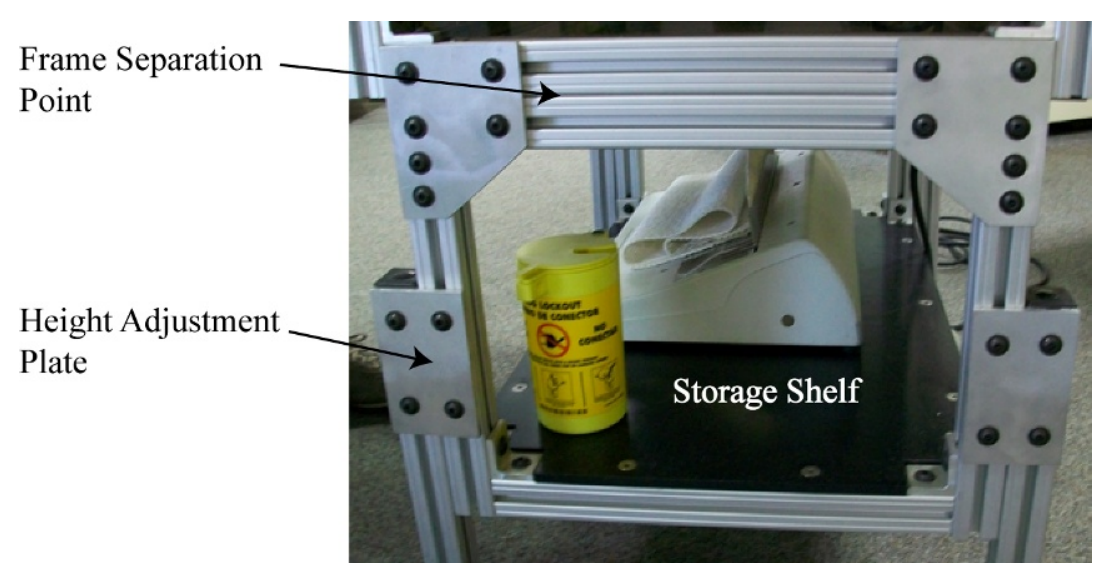

ISSN 1555-9033

FIGURE 3

Braille Press Height Aduustment

\section{Cost, Ease of Manufacturing, and Ease of Assembly:}

Cost, ease of manufacturing, and ease of assembly were all considered when designing the upgraded braille press. Changes to the gearbox and motor specifications reduced the total cost of these components by approximately 200 U. S. dollars. First, by moving the gearmotor under the table top, a less expensive parallel gearbox could be used instead of the right angle worm gearbox in the original design. Second, the motor enclosure was changed from a fan cooled enclosure to an open, drip-proof enclosure. Next, to improve the ease of manufacture and assembly, the frame and enclosure is constructed from aluminum extrusion and plastic. To manufacture the frame assembly, the aluminum extrusion $^{\mathrm{xix}}$ is cut to size, sharp edges are removed, and the pieces are joined using purchased fasteners (see Figure 13). The raw material and purchased part cost of the upgraded braille press is approximately $1,100 \mathrm{U}$. S. dollars per unit, and the press requires approximately 20 hours of student time to manufacture, assemble, and test.

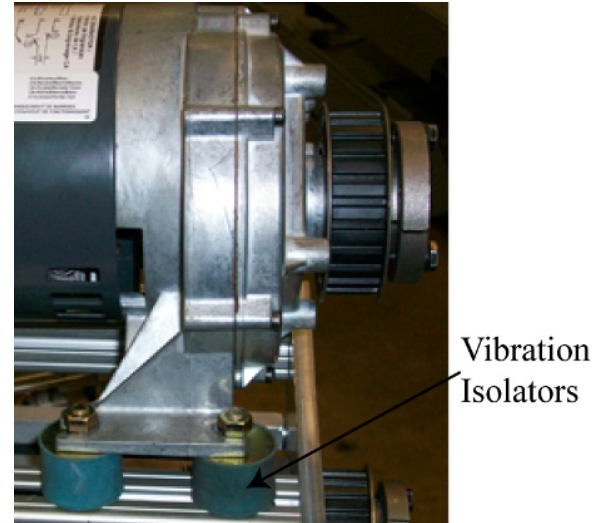

FIGURE 12

VIBRATION ISOLATORS 

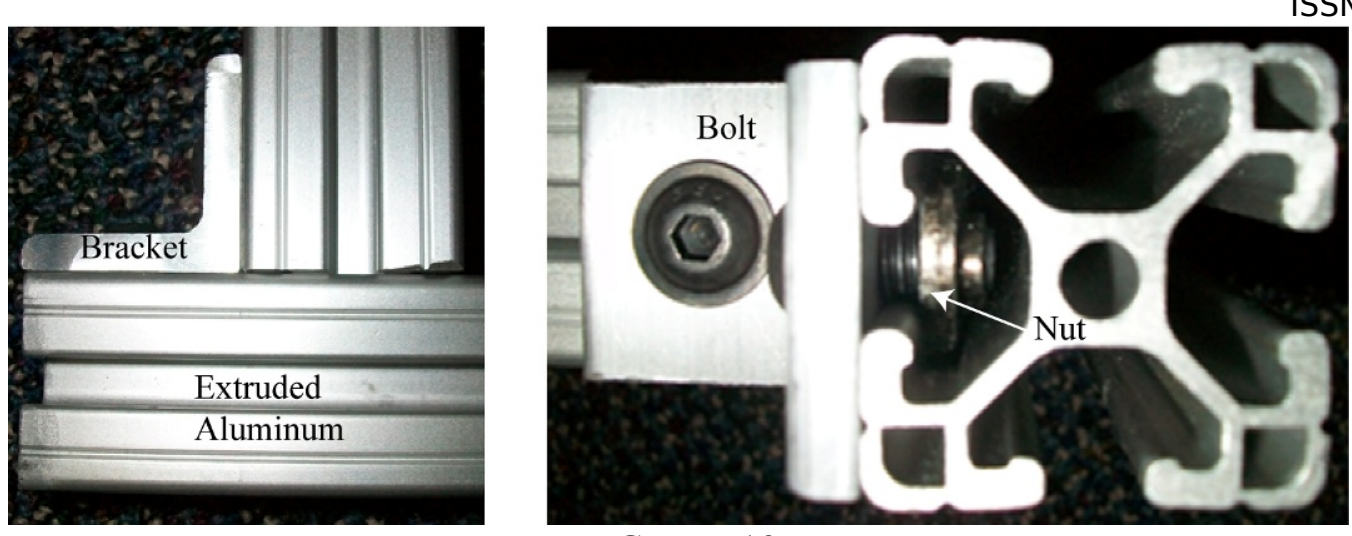

FIGURE 13

Frame ASSEMBLy

\section{Size and Storage Capability:}

Because storage space is at a premium in the work centers, it is important that the footprint of the unit is minimized. During operation, the dimensions of the upgraded braille press are 31 inches wide by 31 inches deep by 37 inches tall. However, a drop-down shelf (see Figure 14) is incorporated into the design to reduce the overall storage footprint to 31 inches wide by 21 inches deep, allowing the unit to fit into a standard closet. Additionally, a shelf is provided (see Figure 11) for the storage of the embossed zinc plates, aluminum jacket, and the binding device. Finally, the size of the unit can be further reduced for transport. The frame can be separated into two components (see location in Figure 11 ) and, as mentioned previously, the drive and roller subassembly can be removed. 

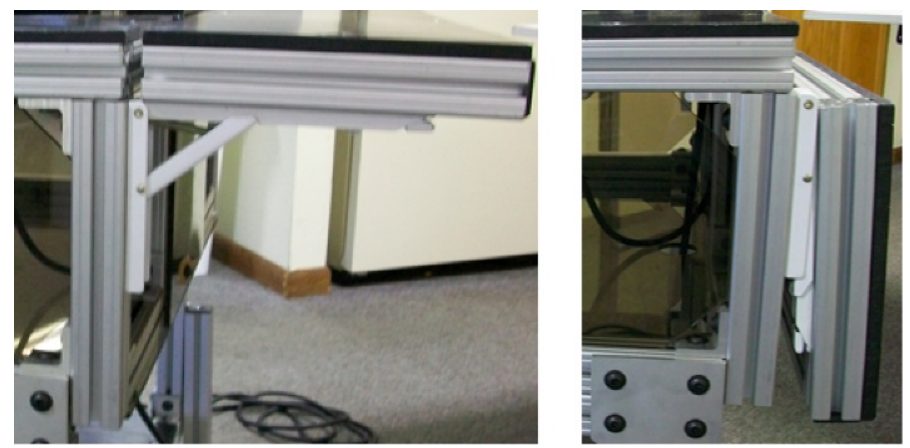

ISSN 1555-9033

FIGURE 14

DRop Down Shelf

\section{Upgraded Braille Press Manufacturing}

The upgraded braille press project provided VUCOE students the opportunity to put into practice the manufacturing skills they learned in their manufacturing courses and laboratories. The students used the following manual machining equipment: 1) a cut-off saw to cut the frame pieces to length, 2) a scrolling saw and table saw to manufacture the plastic guards and table top, 3) a belt sander to remove sharp edges from the components, 4) a drill press for creating holes, and 5) a manual mill in the manufacture of multiple roller subassembly parts. Additionally, the students had the opportunity to use SurfCam ${ }^{\mathrm{xx}}$ computer aided manufacturing (CAM) software to create a computer numerical control (CNC) program of the roller subassembly end plates machining operations. Students transferred their program to a Haas $\mathrm{CNC}$ vertical machining center where the final parts were produced. The CAM software generated tool paths and Haas CNC vertical machining center are shown in Figure 15. Finally, the students assembled the upgraded braille press with hand tools, used gauge blocks to set the distance between rollers, and tested the unit to assure that quality braille print was being produced.
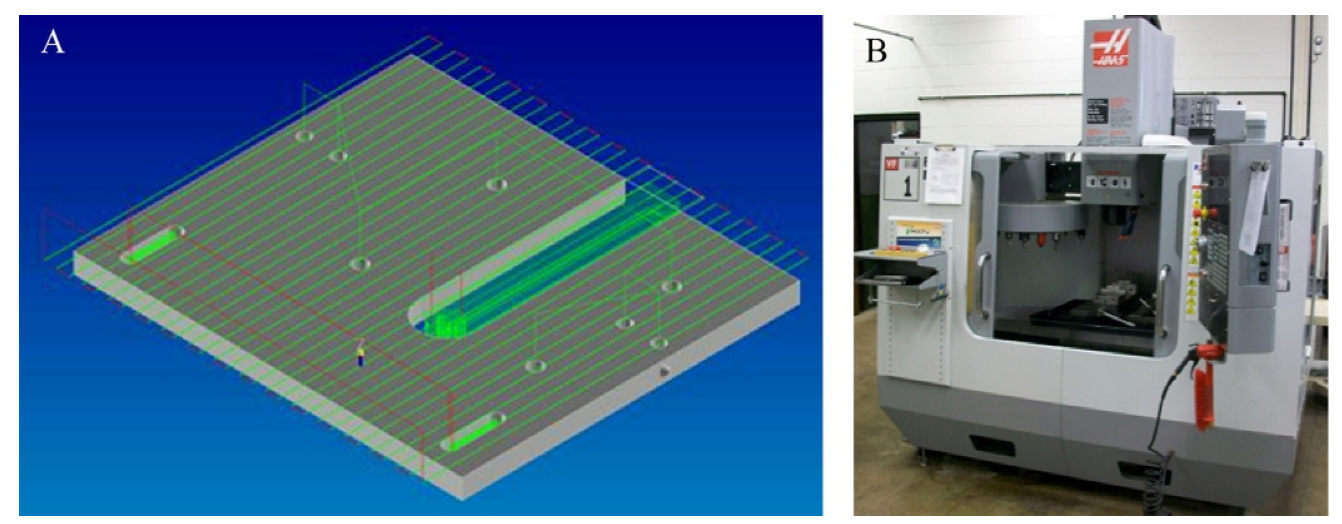

FIGURE 15

(a) Cam generated tool path for roller subassembly plate and (в) haAs CNC Milling Center

\section{Service learning}

There were a number of service learning opportunities for the students participating in the development of the upgraded braille printing press. Project participants developed an appreciation of engineering as a vocation, learned about the vision impaired community, improved their technical communication skills, increased their understanding of the product development life cycle, and improved their design and manufacturing skills. While many of these learning opportunities would be available to 
participants in any extracurricular engineering project, the service component of this project generated student interest and encouraged students to see the project to a successful conclusion.

Developing an Appreciation of Engineering as a Vocation:

One of VUCOE's primary goals is to produce graduates who view engineering as a vocation to which they are called to lead and serve for the good of society. Therefore, it was the faculty's hope that after completing their service on the upgraded braille printing press project, the students would have a deeper appreciation of engineering as a vocation, and not simply a profession. Throughout the project, the students saw first-hand the direct benefit of volunteering their engineering skills to a socially significant cause. Because of the students' efforts, more Christian braille print material will be available to visually impaired individuals. Because more braille print material will be available, these individuals will have a greater opportunity to become literate, and if desired, learn about Christianity. Additionally, the concept of learning in service to others developed in the students a deeper appreciation of the opportunity engineers have to serve society.

\section{Learning About the Vision Impaired International Community:}

Students and faculty both had the opportunity to learn more about the international vision impaired community and the need for braille literacy. Technology is often seen as a panacea for the world problems. In fact, audio books and text-to-speech products have revolutionized the lives for many of the world's blind population. However, there are millions of individuals that do not have access to such devices. In addition, both students and faculty alike found a new understanding of the importance of braille literacy. If a vision impaired individual is not braille literate they are unable to ${ }^{\text {xxi }}: 1$ ) study (not simply reading sequentially) textbooks, tables, and financial statements, 2) learn the workings of spelling, grammar, and punctuation, 3) deliver a speech while referring to notes, and 4) read aloud to either to children or adults.

\section{Improving Technical Communication Skills:}

While developing the upgraded braille press, students had the opportunity to learn the importance of technical verbal communication and improve upon their skills in this area. Throughout most of their engineering education, students have communicated with individuals (i.e., Professors) that have high levels of engineering proficiency. This was often not the case during the specification, design, manufacturing, testing, and installation of the upgraded braille press. Students interfaced and collaborated with non-technical LBW employees and work center volunteers. Therefore, the students were required to communicate in non-technical terms, an endeavor that required additional patience and skill development on their part. This valuable skill, however, is one that all engineers need to develop because upon graduation they will be required to communicate with non-technical sales, marketing, purchasing, and management personnel.

In addition to verbal technical communication, the students were also able to practice their technical writing skills. While the students all considered themselves good writers, they discovered that they still wrote in a linguistic style more suited for a high school book report than an engineering document, journal article, or instruction manual. By thoroughly documenting the engineering project for eventual transfer to LBW and by writing a journal submission, the students were developing the technical writing skills required to communicate to a broad audience how a safe and reliable braille printing press could be developed. 
Understanding the Product Development Life Cycle:

While some engineering classes are project driven, most entry level engineering courses continue to be lecture and homework intensive. This practice of listening to a lecture, attempting a homework assignment, and receiving feedback in the form of a grade is vastly different from most engineered product development cycles. By participating in the upgraded braille press project, the students were able to complete an entire product development cycle including: 1) the gathering of customer requirements, 2) the development of a product specification, 3) the design process including design review sessions with the customer, 4) the manufacture and assembly of the product, 5) the product testing and installation, and 6) the design iteration. The opportunity to work on a multiple iteration life cycle project is a rare opportunity for undergraduate engineering students, even those participating in year-long capstone design sequences. This service learning project allowed for three separate iterations of the braille press over a two year period which helped underscore the need for thorough product testing and continuous improvement.

Improving Design and Manufacturing Skills:

The students participating in the development of the upgraded braille press had the opportunity to develop their design skills beyond their peers who do not participate in extra-curricular engineering activities. For instance, the students received additional practice creating components, assemblies, and actual manufacturing drawings in SolidWorks, ${ }^{\text {xxii }}$ one of the most popular CAD packages available with approximately 1.3 million licenses delivered to date. xxiii This additional practice will serve the students well in any CAD work in which they participate later in their careers. Additionally, the students were required to interact with vendors to determine the most effective externally purchased components (e.g., motor, timing belt, aluminum extrusion, etc.). Finally, because they were designing an actual product, students were required to focus upon reliability, safety, maintenance, ergonomics, manufacturability, and ease of assembly during the design process. This is in direct contrast to many student design projects where a prototype's functionality is the only project goal.

Once the design work was complete, the students were able to improve their manufacturing and assembly skills. All of the custom parts in the upgraded braille press were manufactured by the students in the VUCOE machine shop using manual machine tools, CAM software, and CNC machine tools. Because the students manufactured the parts based on their own SolidWorks prints, the students realized the importance of quality manufacturing drawings. Additionally, to design optimal components and assemblies in terms of cost and functionality, a design engineer must understand how the parts will be manufactured and how the components will be assembled into the final product. By manufacturing the parts and performing the assembly operations themselves, the students improved their knowledge in these areas and became better design engineers.

\section{Conclusions}

VUCOE students, working in collaboration with LBW, have designed and manufactured an upgraded braille press for use in producing Christian print material for the visually impaired. The upgraded braille press is currently operational in Valparaiso, Indiana, at the Prince of Peace work center. Moreover, the upgraded braille press meets the customer requirements in the areas of safety, ergonomics, cost, ease of manufacturing and assembly, and size. By working on this service learning project, VUCOE students have had the opportunity to apply their engineering skills to a valuable project for a charitable organization and to the benefit of visually impaired individuals. The VUCOE has received funding to produce two additional upgraded braille presses. Therefore, future students 
will be able to continue to investigate methods to reduce unit cost, improve manufacturing efficiencies, and participate in a service learning experience.

\section{Acknowledgment}

The authors would like to acknowledge the following for their many contributions to the upgraded braille press project: 1) VUCOE technician, Rich Gudino, 2) VUCOE alumni, Robert Steingass, 3) the VUCOE mechanical engineering department and VU Guild Alumni Association, 4) the Prince of Peace work center volunteers, 5) LBW especially Paul Edie, William LaRue, Pastor Phil Pledger, and Mike Fischer, 6) VUCOE students Dan Toborowski, Bill Burgett, Tom Carbaugh, and Carl Jurss, and 7) VUCOE Dean Kraig Olejniczak. Through the generosity of the VUCOE, a complete print package of the final project is available. Please contact Professors Duncan or Budnik for details.

\section{References}


i $\quad$ Lutheran Braille Workers, Inc. "About Lutheran Braille Workers, Inc," www.lbwinc.org/index.php, (accessed May 25, 2010).

ii World Health Organization Media Centre, "Fact Sheet No. 282: Visual impairment and blindness," World Health Organization, www.who.int/mediacentre/factsheets/fs282/en/print.html, (accessed May 6, 2010).

iii World Health Organization Media Centre, "Prevention of Blindness and Visual Impairment Data and maps," World Health Organization, www.who.int/blindness/data maps/en/index.html, (accessed May 23, 2010).

iv World Health Organization, Global Initiative for the Elimination of Avoidable Blindness (Geneva: World Health Organization Press, 2006), 3.

v $\quad$ World Health Organization Media Centre, "Prevalence of Blindness," World Health Organization, www.who.int/blindness/data maps/blindness.jpg, (accessed May 24, 2010).

vi Tuck Tinsley, "The Use of Federal Quota Registration Data," American Publishing House for the Blind, www.aph.org/advisory/2009adv09.html, (accessed May 6, 2010).

vii Houghton, Mifflin, Harcourt, "American Heritage Student Dictionary."

https://secure.store.hmhbooks.com/, (accessed May 25, 2010).

viii Louis Database, "American Heritage Student Dictionary," American Printing House for the Blind, Inc., http://louis.aph.org/product/American-heritage-students-dictionary-The,53666.aspx? FormatFilter=1, (accessed May 25, 2010).

ix Kevin D. Frick, Allan Foster, "The Magnitude and Cost of Global Blindness: An Increasing Problem That Can Be Alleviated," American Journal of Ophthalmology, no. 135 (2003), 471-476.

$\mathrm{x} \quad$ Ruby Ryles, "The Impact of Braille Reading Skills on Employment, Income, Education, and Reading Habits" Journal of Visual Impairment \& Blindness 90, no. 3 (1996), 219-226.

xi Doug Brent and Diana Brent, "Technologies of Resistance/Resisting Technology: Braille, Computers, and Literacy for the Visually Impaired," Proceedings of the 2000 Inkshed Working Conference, Bowen Island, BC, May, 2000.

xii Houghton, Mifflin, Harcourt, "American Heritage Student Dictionary."

https://secure.store.hmhbooks.com/, (accessed May 25, 2010).

xiii Louis Database, "American Heritage Student Dictionary," American Printing House for the Blind, Inc., http://louis.aph.org/product/American-heritage-students-dictionary-The, 53666.aspx? FormatFilter=1, (accessed May 25, 2010).

xiv American Printing House for the Blind, Inc, "Overview of American Printing House for the Blind," www.aph.org/about/hist.html, (accessed May 24, 2010).

xv Lutheran Braille Workers, Inc. "About Lutheran Braille Workers, Inc," www.lbwinc.org/index.php.

xvi Lutheran Braille Workers, Inc, "Lutheran Braille Workers 2009 Annual Report,"

www.lbwinc.org/docs/newsletters/annualReports/2009AnnualReport.pdf, (accessed May 17, 2010).

xvii Valparaiso University, "Valparaiso University's College of Engineering,"

www.valpo.edu/engineering/about/index.php, (accessed May 25, 2010).

xviii Occupational Safety and Health Administration, United States Department of Labor

"Regulations and Standards," www.osha.gov/pls/oshaweb/owasrch.search_form?

p doc type $=$ STANDARDS\&p toc level $=0 \& p$ keyvalue, $($ accessed May 25, 2010).

xix Faztek, LLC, “T-Slotted Aluminum Solutions," www.faztek.net/downloads.html, (accessed May 27, 2010).

xx Surfware, "SURFCAM Products Overview."

www.surfware.com/surfcam product overview.aspx, (accessed May 20, 2010).

xxi William M. Raeder, "The Case for Braille," National Braille Press, www.nbp.org/ic/nbp/braille/case for_braille.html, (accessed May 18, 2010). 
xxii SolidWorks, "Products" www.solidworks.com/sw/3d-cad-design-software.htm, (accessed May 20, 2010).

xxiii SolidWorks, "Corporate Fact Sheet," www.solidworks.com/sw/docs/Corp_FactSheet_Q1 033110.pdf, (accessed May 20, 2010). 